\title{
Nanodrugs: optimism for emerging trend of multidrug resistance
}

\author{
This article was published in the following Dove Press journal: \\ International Journal of Nanomedicine \\ 3 August 2012 \\ Number of times this article has been viewed
}

\begin{abstract}
Asad U Khan
Medical Microbiology and Molecular Biology Laboratory, Interdisciplinary Biotechnology Unit, Aligarh Muslim University, Aligarh, India
\end{abstract}

\section{Dear Editor}

This is with reference to an article published recently in your journal regarding the antibiotic activity of chitosan-coated silver nanoparticles. ${ }^{1}$ This is an inspiring move towards control of infection caused by multidrug-resistant bacteria which has become a serious problem for clinicians and physicians worldwide. ${ }^{2}$ At the moment, carbapenems are being used as the drugs of choice to combat infections. However, the emergence of carbapenem resistance has changed current remedial approaches in the management of serious infections. One of the latest enzymes, NDM-1 (New Delhi metallo- $\beta$-lactamase-1), first identified in a Swedish patient of Indian origin in $2008,{ }^{3}$ has been key in the development of resistance to almost all antibiotics. Infection caused by NDM-1 producers is widespread on the Indian subcontinent, ${ }^{4}$ and is now emerging in the US and other countries throughout the world. ${ }^{5}$

In the current scenario, it is of the utmost importance to develop an efficient and nontoxic strategy to control microbial infections in humans. Nanomaterials are very attractive in terms of their potential for targeted infection control. Recently, Chiao et $\mathrm{al}^{6}$ developed an effective and safe nanoscale silicate platelet, and its nanohybrid, silver nanoparticle-nanoscale silicate platelet, which can replace antibiotics, is expected to solve the problem of multidrug-resistant bacteria. The efficacy of these nanomaterials has been found to be excellent for protecting Salmonella-infected chicks from septicemia and death. ${ }^{6}$

Meningitis and ventriculitis are major infections and life-threatening complications of external ventricular drainage, and rifampin-impregnated and clindamycinimpregnated silicone catheters and external ventricular drainage devices impregnated with silver nanoparticles and insoluble silver salts have been developed to overcome this problem. ${ }^{7}$ These external ventricular drainage devices have been found to minimize infection rates. Moreover, complications associated with cardiovascular implants may be reduced by modification of the surfaces of these devices using, for example, antimicrobial and antithrombotic agents. In one study, silver nanoparticles were reported to be efficient broad-spectrum antimicrobial agents, and another recent report has proposed that these nanoparticles also have antiplatelet activity. Therefore, Ragaseema et al ${ }^{8}$ have advocated that silver nanoparticles protected by polyethylene glycol may be incorporated with biomaterials to achieve both antimicrobial and antithrombotic activity. Moreover, their cytotoxicity may be minimized to limit adverse affects on tissues and cells. ${ }^{8}$ 
Due to their noteworthy antimicrobial activity, nanoparticles are recognized as hopeful candidates in the fight against pathogens that have developed resistance. With the advent of nanoscale technology comes new hope that engineered silver nanoparticles will solve the worldwide problem of antibiotic resistance. The efficacy of silver nanoparticles with different modifications has been well accepted for the treatment of various systemic and intracellular infections without toxic effects in mammalian cells. hence, they can be proposed as potential therapeutic agents in the current scenario. Furthermore, a novel formulation of nanomaterial that can inhibit bacterial and fungal colonization of surfaces as well as in human and animal systems needs to be developed. Hence the field of nanotechnology and its implications in biology and medicine have opened up new opportunities in the diagnosis and treatment of infectious diseases.

\section{References}

1. Jena P, Mohanty S, Mallik R, et al. Toxicity and antibacterial assessment of chitosan-coated silver nanoparticles on human pathogens and macrophage cells. Int J Nanomedicine. 2012;7:1805-1818.

2. Zarrilli R, Vitale D, Di Popolo A, et al. A plasmid-borne blaOXA-58 gene confers imipenem resistance to Acinetobacter baumannii isolates from a Lebanese hospital. Antimicrob Agents Chemother. 2008;52: 4115-4120.
3. Yong D, Toleman MA, Giske CG, et al. Characterization of a new metallo-beta-lactamase gene, BLA (NDM-1), and a novel erythromycin esterase gene carried on a unique genetic structure in Klebsiella pneumoniae sequence type 14 from India. Antimicrob Agents Chemother. 2009;53:5046-5054.

4. Khan AU, Nordmann P. Spread of carbapenemase NDM-1 producers: the situation in India and what may be proposed. Scand J Infect Dis. 2012;44:531-535.

5. Kumarasamy KK, Toleman MA, Bagaria J, et al. Emergence of a new antibiotic resistance mechanism in India, Pakistan, and the UK: a molecular, biological, and epidemiological study. Lancet Infect Dis. 2010;10:597-602.

6. Chiao SH, Lin SH, Shen CI, et al. Efficacy and safety of nanohybrids comprising silver nanoparticles and silicate clay for controlling Salmonella infection. Int J Nanomedicine. 2012;7:2421-2432.

7. Lemcke J, Depner F, Meier U. The impact of silver nanoparticle-coated and antibiotic-impregnated external ventricular drainage catheters on the risk of infections: a clinical comparison of 95 patients. Acta Neurochir Suppl. 2012;114:347-350.

8. Ragaseema VM, Unnikrishnan S, Kalliyana Krishnan V, et al. The antithrombotic and antimicrobial properties of PEG-protected silver nanoparticle coated surfaces. Biomaterials. 2012;33:3083-3092.
International Journal of Nanomedicine

\section{Publish your work in this journal}

The International Journal of Nanomedicine is an international, peerreviewed journal focusing on the application of nanotechnology in diagnostics, therapeutics, and drug delivery systems throughout the biomedical field. This journal is indexed on PubMed Central, MedLine, CAS, SciSearch $\AA$, Current Contents ${ } /$ Clinical Medicine,

\section{Dovepress}

Journal Citation Reports/Science Edition, EMBase, Scopus and the Elsevier Bibliographic databases. The manuscript management system is completely online and includes a very quick and fair peer-review system, which is all easy to use. Visit http://www.dovepress.com/ testimonials.php to read real quotes from published authors. 